\title{
Corrigendum: Xenopus tropicalis: Joining the Armada in the Fight Against Blood Cancer
}

\section{OPEN ACCESS}

Approved by:

Frontiers in Physiology, Frontiers Media SA, Switzerland

${ }^{*}$ Correspondence:

Kris Vleminckx kris.vleminckx@ugent.be

Specialty section: This article was submitted to Embryonic and Developmental

Physiology,

a section of the journal

Frontiers in Physiology

Received: 15 February 2019 Accepted: 18 February 2019 Published: 14 March 2019

Citation:

Dimitrakopoulou D, Tulkens D, Van Vlierberghe $P$ and Vleminckx K (2019)

Corrigendum: Xenopus tropicalis: Joining the Armada in the Fight Against Blood Cancer. Front. Physiol. 10:210. doi: 10.3389/fphys.2019.00210

\author{
Dionysia Dimitrakopoulou ${ }^{1,2}$, Dieter Tulkens ${ }^{1,2}$, Pieter Van Vlierberghe ${ }^{2,3}$ and \\ Kris Vleminckx ${ }^{1,2,3 *}$ \\ ${ }^{1}$ Department of Biomedical Molecular Biology, Ghent University, Ghent, Belgium, ${ }^{2}$ Cancer Research Institute Ghent (CRIG), \\ Ghent, Belgium, ${ }^{3}$ Department of Biomolecular Medicine, Ghent University, Ghent, Belgium
}

Keywords: Xenopus, CRISPR/Cas9, leukemia, T-ALL, genome editing, thymus, tumor suppressor genes, cancer

\section{A Corrigendum on}

Xenopus tropicalis: Joining the Armada in the Fight Against Blood Cancer

by Dimitrakopoulou, D., Tulkens, D., Van Vlierberghe, P., and Vleminckx, K. (2019). Front. Physiol. 10:48. doi: 10.3389/fphys.2019.00048

An author name was incorrectly spelled as "Pieter Van Vlieberghe." The correct spelling is "Pieter Van Vlierberghe."

The authors apologize for this error and state that this does not change the scientific conclusions of the article in any way. The original article has been updated.

Copyright () 2019 Dimitrakopoulou, Tulkens, Van Vlierberghe and Vleminckx. This is an open-access article distributed under the terms of the Creative Commons Attribution License (CC BY). The use, distribution or reproduction in other forums is permitted, provided the original author(s) and the copyright owner(s) are credited and that the original publication in this journal is cited, in accordance with accepted academic practice. No use, distribution or reproduction is permitted which does not comply with these terms. 